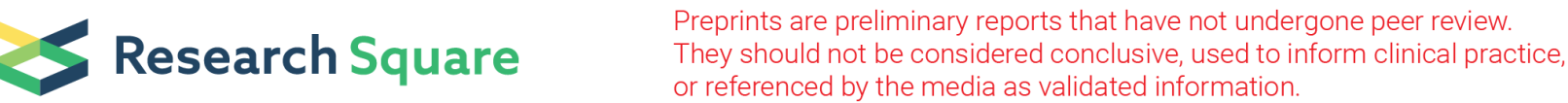

\section{Examining inequality in trials of smoking cessation interventions delivered in primary care: critique and reanalysis of Cochrane reviews}

Jack Michael Birch ( $\nabla$ jack.birch@mrcepid.cam.ac.uk)

University of Cambridge School of Clinical Medicine https://orcid.org/0000-0001-6292-1647

Hajira Dambha-Miller

University of Cambridge Department of Public Health and Primary Care

Simon J Griffin

University of Cambridge Department of Public Health and Primary Care

Gráinne B Hutton

University of Cambridge Department of Public Health and Primary Care

Michael P Kelly

University of Cambridge Department of Public Health and Primary Care

Ann Louise Kinmonth

University of Cambridge Department of Public Health and Primary Care

Research article

Keywords: Smoking cessation, primary care, inequalities, randomised controlled trials, socioeconomic status

Posted Date: March 27th, 2020

DOI: https://doi.org/10.21203/rs.3.rs-18667/v1

License: (c) (1) This work is licensed under a Creative Commons Attribution 4.0 International License.

Read Full License 


\section{Abstract}

\section{Background}

Tobacco smoking is a major cause of chronic disease and premature mortality. Its effects are socially patterned. Observational studies show that low socioeconomic status [SES] is associated with higher smoking prevalence and lower cessation rates. Interventions in primary care may improve or exacerbate health inequalities depending on socioeconomic patterning of access and uptake. Data on the impact of trials of smoking cessation interventions delivered in primary care on health inequalities by SES have not been synthesised. Aims To examine the impact of smoking cessation interventions delivered in primary care on inequalities in health by socioeconomic status.

Methods

We searched the Cochrane database of systematic reviews from inception until June 2019. We included reviews of trials of smoking cessation interventions delivered in primary care and published in English.

Findings

We identified eight Cochrane reviews (413 studies). Eighty five studies included an intervention delivered in primary care. Interventions were: behavioural, (very) brief advice, and pharmacological (including nicotine replacement therapy). Full texts were accessed for 70 studies; 17 reported an SES measure. Two studies targeted low-SES groups. There was heterogeneity in SES measures used across the studies, which included household income, occupational level and social class. Three studies analysed SES as a predictor of effectiveness of the smoking cessation intervention; none found effectiveness differed by SES.

Implications

This summary and critique of Cochrane reviews demonstrates that trials of smoking cessation interventions delivered in primary care are not designed to allow analysis of effects by measures of SES. Studies rarely reported SES of participants at baseline and hardly ever as a predictor of smoking cessation. Our work highlights the need for routine reporting of SES amongst trials and greater consensus in included measures. Consistent reporting of a core set of SES indicators will enable testing of similarities between trial groups and differential effects by SES.

\section{Introduction}

Tobacco smoking is extremely harmful. It is a major cause of non-communicable diseases [NCDs] (1) such as cardiovascular disease (2) and at least 15 types of cancer (3). Globally, there are more than eight million deaths per year attributed to tobacco use (4). In the 20th century, there were 100 million deaths associated with tobacco use and this is projected to rise to an estimated one billion deaths in the 21st century (5). The total costs of smoking to the global economy in 2012 was estimated to be 
US\$1,436 billion, equating to $1.8 \%$ of the world's annual gross domestic product (6). Healthcare expenditure related to tobacco was estimated at US\$422 billion. In the UK alone, the direct cost to the National Health Service is estimated to be up to $£ 5.1$ billion $(7,8)$ with a broader cost to society of $£ 12.7$ billion (9).

The burden of harms from smoking, as well as the effectiveness of interventions for smoking cessation, vary by population subtype which lead to inequalities in health outcomes. These inequalities are often hidden by study-level results that do not consider differential effects. The subgroups that inequalities occur in are included in the so-called 'PROGRESS-Plus' acronym, which ensures that health inequalities are considered across a broad range socially stratifying factors (10). PROGRESS-Plus is an acronym for: Place of residence, Race/ethnicity, Occupation, Gender/sex, Religion, Education, Social Capital, Socioeconomic status [SES] plus personal characteristics that attract discrimination, features of relationships, and time-dependant relationships $(10,11)$. All of these factors are known to have some bearing on aspects of health, particularly SES. A number of measures, both ecological and individual, are used to define SES (12). Ecological measures include median household income from census data and local indices of multiple deprivation defined by post code (in the UK); individual measures can include occupation type and income.

There is a strong association between SES and smoking. Observational studies show that deprivation is associated with higher smoking prevalence (13) and lower cessation rates (14). In relation to prevalence, in the UK $33 \%$ of males in the most deprived quintile smoke, compared to $14 \%$ in the least deprived (15). A similar difference occurs in females; $26 \%$ smoke in the most deprived quintile versus $10 \%$ in the least deprived (15). Similar disparities in smoking are seen in other countries across the world (16-19). Social inequalities in risk factors for NCDs, such as smoking, poor diet, excessive alcohol consumption and obesity, account for more than half of health inequalities (20). These risk factors have been shown to cluster and co-occur, with those from a more deprived SES being the most likely to have multiple risk factors $(21,22)$.

Evidence has suggested that smoking cessation interventions in primary care could be a cost-effective approach to reducing a population's smoking prevalence (23-26). These interventions include behavioural interventions (such as brief and very brief advice delivered by a practitioner and leaflets and other information provision), referral to stop smoking services, nicotine replacement therapy and other pharmacological therapies such as varenicline and bupropion. They may, however, improve or exacerbate inequalities in smoking behaviour and associated health outcomes, according to whether design, implementation, accessibility, uptake and outcome are socio-economically patterned (27).

From an equity perspective, strategies are needed to ensure that an improvement in total health and a reduction in inequality are achieved concurrently. These strategies have been classified as 'upstream' including legal remedies and policies that require little individual agency, or 'downstream' (28).

Downstream interventions tend to feature more individual level approaches, such as those delivered by healthcare practitioners in primary care, and require high individual agency. Downstream interventions 
may therefore be more likely to exacerbate health inequalities than upstream interventions (28). Much of the evidence on inequalities generated by downstream smoking cessation interventions comes from observational research.

Few data from existing systematic reviews of the impact of smoking cessation interventions on health inequalities come from randomised controlled trials [RCTs] (5/30 studies in Smith et al., (29) and 6/29 studies in Brown et al., (30)). We focus on RCTs as a source of high-quality evidence to assess if there are inequalities in outcomes of smoking cessation interventions delivered in primary care. We aimed to identify if previous Cochrane Reviews consider the effectiveness of smoking cessation interventions by SES, describe the frequency and type of measures of SES reported in trials of smoking cessation interventions and synthesise data from individual trials of smoking cessation interventions which consider differential effectiveness by SES.

\section{Methods}

We followed the Preferred Reporting Items for Systematic Reviews and Meta-Analyses Equity Reporting Guidelines (31) (included in Additional file 1).

\section{Eligibility Criteria}

Two sets of eligibility were required for the different levels of this study (Cochrane review and individual study). Eligible reviews included trials of smoking cessation interventions delivered in primary care by a primary care practitioner. Primary care practitioner was defined as nurse or doctor (such as general practitioner or family doctor).

For the individual trials, the eligibility criteria were: trials of a smoking cessation intervention delivered in primary care by a primary care practitioner. Due to resource limitations, we restricted searches to papers published in the English language and with a full-text available via the University of Cambridge Medical Library. This library has access to an extensive range of medical and health literature databases (34). The following intervention types were included: behavioural interventions (including leaflets/booklets, brief advice and very brief advice); pharmacological (nicotine replacement therapy and medication such as varenicline and bupropion); and any combination of these interventions. These interventions were chosen because they are the predominant smoking cessation interventions delivered in primary care, as indicated in a position statement by the International Primary Care Respiratory Group in 2017 (35).

No additional restrictions were placed on geography, study design or age of participants to those used in each Cochrane review.

\section{Search Strategy And Study Selection}


The approach to literature searching was developed in consultation with the St John's Reading Group on Health Inequalities, University of Cambridge, who are topic experts on health inequalities and primary care (32)

We searched the Cochrane Database of Systematic Reviews (CDSR) for reviews containing relevant literature from database inception until June 2019. Initial searches of the CDSR indicated that a highly sensitive search strategy would return a manageable number of systematic reviews to screen. Hence, a one line search strategy was used (Tobacco OR Smoking). Titles and abstracts of the Cochrane reviews identified were downloaded into Endnote X7 reference manager software, where they were screened to identify if they included trials meeting the eligibility criteria described below. Only the most recent version of each review was included.

Titles and abstracts of the trials included in the included Cochrane Reviews were uploaded into the Rayyan web application for screening titles and abstracts (33). All trials were double-screened for inclusion by $\mathrm{JB}$ and $\mathrm{GH}$; disagreements were resolved through discussion.

\section{Data Extraction}

The following data were extracted for each study using a customised data-extraction form: trial design, country, measure of SES reported, and selected other PROGRESS-Plus equity measures reported. Where a measure of SES was reported, the following additional data were extracted: if SES was reported prior to randomisation, if SES was reported following randomisation, if SES was reported or analysed at outcome, overall, primary outcome (cessation or adherence), effect size, and risk of bias judgement. Data were extracted by JB and checked by $\mathrm{GH}$.

\section{Data Analysis And Synthesis}

Heterogeneity in intervention types and measures of SES meant it was not possible to conduct a metaanalysis. Narrative synthesis was conducted at Cochrane review level, to consider if differential effectiveness by SES was explicitly referred to, and at individual trial level.

\section{Results}

\section{Review-level Synthesis}

The search of the CDSR returned 223 Cochrane reviews. Of these, eight contained trials of smoking cessation interventions delivered in primary care by a GP, nurse practitioner or family doctor (36-43). An overview of these included Cochrane reviews is provided in Table 1. None of the reviews considered if the effectiveness of trials of smoking cessation interventions differed by SES, nor reported the SES profile of trials included in the review. 
Table 1

Summary of Cochrane reviews which include literature on smoking cessation interventions delivered in primary care

\begin{tabular}{|c|c|c|c|c|c|}
\hline Author & Year & Title & $\begin{array}{l}\text { Number of } \\
\text { studies }\end{array}$ & $\begin{array}{l}\text { Number of } \\
\text { studies in } \\
\text { primary } \\
\text { care }\end{array}$ & Author's conclusions \\
\hline $\begin{array}{l}\text { Stead et } \\
\text { al. (36) }\end{array}$ & 2013 & $\begin{array}{l}\text { Physician advice } \\
\text { for smoking } \\
\text { cessation }\end{array}$ & 42 & 31 & $\begin{array}{l}\text { Simple advice has a small } \\
\text { effect on cessation rates. } \\
\text { Assuming an unassisted } \\
\text { quit rate of } 2 \text { to } 3 \% \text {, a brief } \\
\text { advice intervention can } \\
\text { increase quitting by a furthe } \\
1 \text { to } 3 \% \text {. Additional } \\
\text { components appear to have } \\
\text { only a small effect, though } \\
\text { there is a small additional } \\
\text { benefit of more intensive } \\
\text { interventions compared to } \\
\text { very brief interventions. }\end{array}$ \\
\hline $\begin{array}{l}\text { Hollands } \\
\text { et al. (37) }\end{array}$ & 2015 & $\begin{array}{l}\text { Interventions to } \\
\text { increase } \\
\text { adherence to } \\
\text { medications for } \\
\text { tobacco } \\
\text { dependence }\end{array}$ & 8 & 1 & $\begin{array}{l}\text { There is some evidence that } \\
\text { interventions that devote } \\
\text { special attention to } \\
\text { improving adherence to } \\
\text { smoking cessation } \\
\text { medication through } \\
\text { providing information and } \\
\text { facilitating problem-solving } \\
\text { can improve adherence, } \\
\text { though the evidence for this } \\
\text { is not strong and is limited } \\
\text { in both quality and quantity. } \\
\text { There is some evidence that } \\
\text { such interventions improve } \\
\text { the chances of achieving } \\
\text { abstinence but again the } \\
\text { evidence for this is relatively } \\
\text { weak. }\end{array}$ \\
\hline
\end{tabular}




\begin{tabular}{|c|c|c|c|c|c|}
\hline Author & Year & Title & $\begin{array}{l}\text { Number of } \\
\text { studies }\end{array}$ & $\begin{array}{l}\text { Number of } \\
\text { studies in } \\
\text { primary } \\
\text { care }\end{array}$ & Author's conclusions \\
\hline $\begin{array}{l}\text { Stead et } \\
\text { al. (38) }\end{array}$ & 2016 & $\begin{array}{l}\text { Combined } \\
\text { pharmacotherapy } \\
\text { and behavioural } \\
\text { interventions for } \\
\text { smoking } \\
\text { cessation }\end{array}$ & 53 & 8 & $\begin{array}{l}\text { Interventions that combine } \\
\text { pharmacotherapy and } \\
\text { behavioural support } \\
\text { increase smoking cessation } \\
\text { success compared to a } \\
\text { minimal intervention or } \\
\text { usual care. Updating this } \\
\text { review with an additional } 12 \\
\text { studies ( } 5,000 \text { participants) } \\
\text { did not materially change } \\
\text { the effect estimate. } \\
\text { Although trials differed in } \\
\text { the details of their } \\
\text { populations and } \\
\text { interventions, we did not } \\
\text { detect any factors that } \\
\text { modified treatment effects } \\
\text { apart from the recruitment } \\
\text { setting. We did not find } \\
\text { evidence from indirect } \\
\text { comparisons that offering } \\
\text { more intensive behavioural } \\
\text { support was associated with } \\
\text { larger treatment effects. }\end{array}$ \\
\hline $\begin{array}{l}\text { van Eerd } \\
\text { et al. (39) }\end{array}$ & 2016 & $\begin{array}{l}\text { Smoking } \\
\text { cessation for } \\
\text { people with } \\
\text { chronic } \\
\text { obstructive } \\
\text { pulmonary } \\
\text { disease }\end{array}$ & 16 & 2 & $\begin{array}{l}\text { We found high-quality } \\
\text { evidence in a meta-analysis } \\
\text { including four ( } 1,540 \\
\text { participants) of the } 16 \\
\text { included studies that a } \\
\text { combination of behavioural } \\
\text { treatment and } \\
\text { pharmacotherapy is } \\
\text { effective in helping smokers } \\
\text { with COPD to quit smoking. } \\
\text { Furthermore, we conclude } \\
\text { that there is no convincing } \\
\text { evidence for preferring any } \\
\text { particular form of } \\
\text { behavioural or } \\
\text { pharmacological treatment. }\end{array}$ \\
\hline
\end{tabular}




\begin{tabular}{|c|c|c|c|c|c|}
\hline Author & Year & Title & $\begin{array}{l}\text { Number of } \\
\text { studies }\end{array}$ & $\begin{array}{l}\text { Number of } \\
\text { studies in } \\
\text { primary } \\
\text { care }\end{array}$ & Author's conclusions \\
\hline $\begin{array}{l}\text { Rice et al. } \\
(40)\end{array}$ & 2017 & $\begin{array}{l}\text { Nursing } \\
\text { interventions for } \\
\text { smoking } \\
\text { cessation }\end{array}$ & 59 & 21 & $\begin{array}{l}\text { There is moderate quality } \\
\text { evidence that behavioural } \\
\text { support to motivate and } \\
\text { sustain smoking cessation } \\
\text { delivered by nurses can lead } \\
\text { to a modest increase in the } \\
\text { number of people who } \\
\text { achieve prolonged } \\
\text { abstinence. There is } \\
\text { insufficient evidence to } \\
\text { assess whether more } \\
\text { intensive interventions, } \\
\text { those incorporating } \\
\text { additional follow-up, or } \\
\text { those incorporating } \\
\text { pathophysiological } \\
\text { feedback are more effective } \\
\text { than one-off support. There } \\
\text { was no evidence that the } \\
\text { effect of support differed by } \\
\text { patient group or across } \\
\text { healthcare settings. }\end{array}$ \\
\hline $\begin{array}{l}\text { Lancaster } \\
\& \text { Stead } \\
(41)\end{array}$ & 2017 & $\begin{array}{l}\text { Individual } \\
\text { behavioural } \\
\text { counselling for } \\
\text { smoking } \\
\text { cessation }\end{array}$ & 49 & 6 & $\begin{array}{l}\text { There is high-quality } \\
\text { evidence that individually- } \\
\text { delivered smoking cessation } \\
\text { counselling can assist } \\
\text { smokers to quit. There is } \\
\text { moderate quality evidence } \\
\text { of a smaller relative benefit } \\
\text { when counselling is used in } \\
\text { addition to } \\
\text { pharmacotherapy, and of } \\
\text { more intensive counselling } \\
\text { compared to a brief } \\
\text { counselling intervention. }\end{array}$ \\
\hline
\end{tabular}




\begin{tabular}{|c|c|c|c|c|c|}
\hline Author & Year & Title & $\begin{array}{l}\text { Number of } \\
\text { studies }\end{array}$ & $\begin{array}{l}\text { Number of } \\
\text { studies in } \\
\text { primary } \\
\text { care }\end{array}$ & Author's conclusions \\
\hline $\begin{array}{l}\text { Hartmann- } \\
\text { Boyce et } \\
\text { al. (42) }\end{array}$ & 2018 & $\begin{array}{l}\text { Nicotine } \\
\text { replacement } \\
\text { therapy versus } \\
\text { control for } \\
\text { smoking } \\
\text { cessation }\end{array}$ & 136 & 21 & $\begin{array}{l}\text { There is high-quality } \\
\text { evidence that all of the } \\
\text { licensed forms of NRT (gum, } \\
\text { transdermal patch, nasal } \\
\text { spray, inhalator and } \\
\text { sublingual tablets/lozenges) } \\
\text { can help people who make a } \\
\text { quit attempt to increase their } \\
\text { chances of successfully } \\
\text { stopping smoking. NRTs } \\
\text { increase the rate of quitting } \\
\text { by } 50-60 \% \text {, regardless of } \\
\text { setting, and further research } \\
\text { is very unlikely to change } \\
\text { our confidence in the } \\
\text { estimate of the effect. The } \\
\text { relative effectiveness of NRT } \\
\text { appears to be largely } \\
\text { independent of the intensity } \\
\text { of additional support } \\
\text { provided to the individual. } \\
\text { Provision of more intense } \\
\text { levels of support, although } \\
\text { beneficial in facilitating the } \\
\text { likelihood of quitting, is not } \\
\text { essential to the success of } \\
\text { NRT. NRT often causes } \\
\text { minor irritation of the site } \\
\text { through which it is } \\
\text { administered, and in rare } \\
\text { cases can cause non- } \\
\text { ischaemic chest pain and } \\
\text { palpitations. }\end{array}$ \\
\hline
\end{tabular}




\begin{tabular}{|c|c|c|c|c|c|}
\hline Author & Year & Title & $\begin{array}{l}\text { Number of } \\
\text { studies }\end{array}$ & $\begin{array}{l}\text { Number of } \\
\text { studies in } \\
\text { primary } \\
\text { care }\end{array}$ & Author's conclusions \\
\hline $\begin{array}{l}\text { Hartmann- } \\
\text { Boyce et } \\
\text { al. (43) }\end{array}$ & 2019 & $\begin{array}{l}\text { Additional } \\
\text { behavioural } \\
\text { support as an } \\
\text { adjunct to } \\
\text { pharmacotherapy } \\
\text { for smoking } \\
\text { cessation }\end{array}$ & 83 & 10 & $\begin{array}{l}\text { There is high-certainty } \\
\text { evidence that providing } \\
\text { behavioural support in } \\
\text { person or via telephone for } \\
\text { people using } \\
\text { pharmacotherapy to stop } \\
\text { smoking increases quit } \\
\text { rates. Increasing the amount } \\
\text { of behavioural support is } \\
\text { likely to increase the chance } \\
\text { of success by about } 10- \\
20 \% \text {, based on a pooled } \\
\text { estimate from } 65 \text { trials. } \\
\text { Subgroup analysis suggests } \\
\text { that the incremental benefit } \\
\text { from more support is similar } \\
\text { over a range of levels of } \\
\text { baseline support. More } \\
\text { research is needed to assess } \\
\text { the effectiveness of specific } \\
\text { components that comprise } \\
\text { behavioural support. }\end{array}$ \\
\hline \multicolumn{3}{|c|}{ Total number of papers } & $\begin{array}{l}413 \text { (446 } \\
\text { including } \\
\text { duplicates) }\end{array}$ & $\begin{array}{l}85 \text { (101 } \\
\text { including } \\
\text { duplicates) }\end{array}$ & \\
\hline
\end{tabular}


Table 2

Data available in papers reporting SES identified from the chosen Cochrane reviews

\begin{tabular}{|c|c|c|c|c|c|c|}
\hline Author & Intervention & $\begin{array}{l}\text { Measure of SES } \\
\text { Reported }\end{array}$ & $\begin{array}{l}\text { SES } \\
\text { Reported } \\
\text { at } \\
\text { Baseline }\end{array}$ & $\begin{array}{l}\text { SES } \\
\text { Reported by } \\
\text { Randomised } \\
\text { Group }\end{array}$ & $\begin{array}{l}\text { SES } \\
\text { Reported } \\
\text { or } \\
\text { Analysed } \\
\text { at } \\
\text { Outcome? }\end{array}$ & $\begin{array}{l}\text { Risk of } \\
\text { Bias }\end{array}$ \\
\hline $\begin{array}{l}\text { Ahluwalia } \\
\text { et al., } \\
\text { (2008) }\end{array}$ & NRT & Income & Yes & No & No & Low \\
\hline $\begin{array}{l}\text { Aveyard } \\
\text { et al., } \\
\text { (2003) }\end{array}$ & Behavioural & Not stated & No & No & No & Unclear \\
\hline $\begin{array}{l}\text { Bock et } \\
\text { al., (2014) }\end{array}$ & $\begin{array}{l}\text { NRT and } \\
\text { VBA }\end{array}$ & $\begin{array}{l}\text { Health insurance } \\
\text { status: Uninsured } \\
\text { or recipient of } \\
\text { Medicaid indicated } \\
\text { low-SES }\end{array}$ & \multicolumn{3}{|c|}{$\begin{array}{l}\text { Intervention was targeted at those with } \\
\text { low-SES, so no other socioeconomic } \\
\text { groups were included as a } \\
\text { comparison. }\end{array}$} & High \\
\hline $\begin{array}{l}\text { Haas et } \\
\text { al., (2015) }\end{array}$ & $\begin{array}{l}\text { Behavioural } \\
\text { and NRT }\end{array}$ & $\begin{array}{l}\text { Median household } \\
\text { income using } \\
\text { estimates from } \\
\text { census data }\end{array}$ & \multicolumn{3}{|c|}{$\begin{array}{l}\text { Intervention was targeted at those with } \\
\text { a low-SES so no other socioeconomic } \\
\text { groups were included as a } \\
\text { comparison. }\end{array}$} & Low \\
\hline $\begin{array}{l}\text { Jamrozik } \\
\text { et al., } \\
\text { (1984) }\end{array}$ & NRT & Social class & Yes & Yes & No & High \\
\hline $\begin{array}{l}\text { Lancaster } \\
\text { et al., } \\
\text { (1999) }\end{array}$ & Behavioural & $\begin{array}{l}\text { Social class } \\
\text { (Occupation level) }\end{array}$ & Yes & Yes & No & Unclear \\
\hline $\begin{array}{l}\text { Lou et al., } \\
\text { (2013) }\end{array}$ & Behavioural & Household income & Yes & Yes & Yes & High \\
\hline $\begin{array}{l}\text { Marshall } \\
\text { and Raw } \\
\text { (1985) }\end{array}$ & $\begin{array}{l}\text { NRT and } \\
\text { Behavioural }\end{array}$ & $\begin{array}{l}\text { Social class } \\
\text { (Occupation level) }\end{array}$ & Yes & No & No & Unclear \\
\hline $\begin{array}{l}\text { Marteau } \\
\text { et al., } \\
(2012)\end{array}$ & $\begin{array}{l}\text { NRT and } \\
\text { Behavioural }\end{array}$ & Not stated & Yes & Yes & No & Unclear \\
\hline $\begin{array}{l}\text { OXCHECK } \\
\text { (1994) }\end{array}$ & $\begin{array}{l}\text { (Health } \\
\text { Check) }\end{array}$ & Social class & Yes & Yes & No & High \\
\hline $\begin{array}{l}\text { Richmond } \\
\text { et al., } \\
\text { (1993) }\end{array}$ & $\begin{array}{l}\text { Behavioural, } \\
\text { Brief Advice } \\
\text { and NRT }\end{array}$ & Not reported & Yes & No & No & Unclear \\
\hline
\end{tabular}




\begin{tabular}{|c|c|c|c|c|c|c|}
\hline Author & Intervention & $\begin{array}{l}\text { Measure of SES } \\
\text { Reported }\end{array}$ & $\begin{array}{l}\text { SES } \\
\text { Reported } \\
\text { at } \\
\text { Baseline }\end{array}$ & $\begin{array}{l}\text { SES } \\
\text { Reported by } \\
\text { Randomised } \\
\text { Group }\end{array}$ & $\begin{array}{l}\text { SES } \\
\text { Reported } \\
\text { or } \\
\text { Analysed } \\
\text { at } \\
\text { Outcome? }\end{array}$ & $\begin{array}{l}\text { Risk of } \\
\text { Bias }\end{array}$ \\
\hline $\begin{array}{l}\text { Sanders } \\
\text { et al., } \\
\text { (1989) }\end{array}$ & Brief advice & Social class & Yes & No & No & High \\
\hline $\begin{array}{l}\text { Stanton } \\
\text { et al., } \\
\text { (2015) }\end{array}$ & Brief Advice & Income & Yes & Yes & Yes & Unclear \\
\hline $\begin{array}{l}\text { van } \\
\text { Rossem } \\
\text { et al., } \\
(2017)\end{array}$ & $\begin{array}{l}\text { Behavioural } \\
\text { and Brief } \\
\text { Advice }\end{array}$ & $\begin{array}{l}\text { Combination of } \\
\text { education and } \\
\text { income }\end{array}$ & Yes & Yes & No & Low \\
\hline $\begin{array}{l}\text { Wewers et } \\
\text { al., (2009) }\end{array}$ & $\begin{array}{l}\text { NRT and } \\
\text { Behavioural }\end{array}$ & $\begin{array}{l}\text { Life-course } \\
\text { socioeconomic } \\
\text { position }\end{array}$ & Yes & Yes & No & Low \\
\hline $\begin{array}{l}\text { Williams } \\
\text { et al., } \\
(2002)\end{array}$ & Behavioural & Household income & Yes & Yes & Yes & Unclear \\
\hline $\begin{array}{l}\text { Zwar et } \\
\text { al., (2015) }\end{array}$ & Behavioural & Postcode & Yes & No & No & Unclear \\
\hline
\end{tabular}

\section{Trial-level Synthesis}

Across the eight Cochrane reviews, there were 413 studies (446 including duplicates). Eighty-five evaluated interventions delivered in primary care by a primary care practitioner, of which 70 fully met the inclusion criteria for our study (Fig. 1 PRISMA flow diagram (44)). Six studies were excluded as these were not in the English language and a further nine did not have full-texts available. Abstracts were available for 12 of these papers but made no reference to SES in only one abstract reported subgroup analysis by any other factor (gender) (45).

An overview of each of the 70 studies is included in Additional file 2. Briefly, the publication date ranged $w$ between 1972 and 2016; sample size ranged from 90 (46) to 12,472 (47); and studies were from 15 different countries globally: the UK $(n=20)$, USA $(n=19)$, Canada $(n=6)$, the Netherlands $(n=5)$, Australia $(n=4)$, Spain $(n=3)$, Germany $(n=3)$, Sweden $(n=2)$, as well as single studies from each of Syria, Denmark, France, Italy, Norway and Switzerland. One study sampled from several countries. 
Seventeen of the 70 studies (24\%) reported a measure of SES (48-64). For comparison, gender/sex was reported in 60 studies; $35 / 70$ studies reported education; $17 / 70$ studies reported race/ethnicity; 17/70 studies reported occupation; and religion was reported in $0 / 70$ studies.

There was heterogeneity in the measure of SES used across the studies. Single individual measures of SES used were personal income, household income and health insurance status. Two studies used combined measures for individual level SES. Wewers et al., (64) reported life course socioeconomic position, which took into account factors from an individual's childhood (using parental education and living status) and adulthood (education, health insurance and poverty-income ratio) to assign a socioeconomic position. The other combined measure was reported by van Rossem et al., (61) who used a combination of education and income. Ecological measures were also used based on estimates of the population local to the participant. These included: social class, median household income from census data, and postal code.

Generally, where a measure of SES was reported, it was used to describe the sample at baseline to demonstrate similarity of randomised groups; Only three studies reported that SES was considered in relation to outcome $(54,60,62)$.

Lou et al., (54) considered the effectiveness of a behavioural intervention (physician advice consisting of a 5-8 minute discussion of the positives of quitting smoking) to improve smoking cessation in a sample of participants with chronic obstructive pulmonary disorder in China, whose smoking status was confirmed at baseline using an exhaled carbon monoxide measurement. They reported the effectiveness by SES (household income). In the high household income group, significantly more people in the intervention group ceased smoking and remained abstinent from smoking than the control group from month 31 to month 48 following intervention (difference $36.6 \%$ (41.2\% vs $4.6 \%$ ), $95 \% \mathrm{Cl} 31.3-42.4, \mathrm{p}<$ 0.001 ). Similarly, in the low household income group significantly more people in the intervention group ceased smoking and remained abstinent than in the control group (difference $36.6 \%$ (41.2\% vs $4.6 \%$ ), $95 \% \mathrm{Cl} 31.3-42.4, \mathrm{p}<0.001)$. As the authors did not consider if abstinence in the intervention group differed in low versus high household income groups, we performed a chi-squared test using the available data. There was no significant association between abstinence from smoking and SES $\left(\chi^{2}=\right.$ $0.0082, p=0.928$ ). Williams et al. considered the effectiveness of physicians adopting either an autonomy-supportive or controlling interpersonal style when counselling smokers according to the National Cancer Institute guidelines in the USA (62). Income was the measure of SES. As the data were continuous, correlations were reported to consider the association between SES and abstinence. The association was not statistically significant $(p>.05)$ at 6,12 or 30 months. It was not possible to access the supplementary file for Stanton et al., (48) which included the relevant analysis. However, it was suggested in the main paper that SES was not a significant predictor of abstinence from smoking at 12months following the intervention. Therefore, none of the three studies found an association between effectiveness and SES. 


\section{Trials Targeting Low-ses Groups}

Two studies targeted smoking cessation interventions at low-SES groups. Bock et al., (50) considered if a behavioural intervention, 'motivational enhancement', in addition to usual care (NRT plus brief physician advice) increased smoking cessation amongst low-income smokers in the USA. The intervention group did not have significantly higher abstinence from smoking at 12 months than the control group (odds ratio: $1.26,95 \% \mathrm{Cl} 0.96-1.66, \mathrm{p}=0.09$ ). Haas et al., (51) studied whether, in addition to usual care: 1 ) telephone-based counselling, 2) NRT, 3) community-based referrals to address social mediators of smoking, or 4) integration of all components 1-3, increased abstinence amongst low-SES smokers in the USA. Combining all intervention groups, there was a statistically significant higher quite rate from smoking in the intervention group compared to the usual care only group at nine month study end-point (17.8\% vs $8.1 \%$, odds ratio: $2.5,95 \% \mathrm{Cl}: 1.5-4.0)$.

\section{Discussion}

We have shown that it is not currently possible to use the Cochrane Reviews of trials to examine the impact of smoking cessation interventions delivered in primary care on inequalities in health by socioeconomic status. None of the included Cochrane Reviews considered if the effectiveness of trials of smoking cessation interventions differed by SES. Within reviews we found that SES is rarely reported in randomised trials of smoking cessation interventions delivered in primary care. None of the three studies that reported SES in relation to outcome found an association. A number of different measures of SES are used. Where reported, measures are used to describe the sample at baseline or to demonstrate similarity of randomised groups rather than to consider if effectiveness differs by SES.

\section{Comparison To Existing Literature}

To the best of our knowledge, this is the first study to have considered the reporting of SES in trials of smoking cessation interventions delivered in primary care. Our findings are similar to those found in systematic reviews of other interventions delivered in primary care. The first was a systematic review of RCTs of primary care-based physical activity interventions where only three out of 171 RCTs reported a measure of SES (65). Two of these three trials found no difference in effectiveness by SES; the remaining study did not provide a clear indication of whether a differential effect was present. The second, a systematic review of primary care interventions to aid management of multimorbidity found that none of the ten studies analysed effects by SES, while three out of the ten reported SES at baseline (66).

Together, our findings, alongside previews reviews, suggest that there is insufficient trial evidence to consider if interventions delivered in primary care are equitable in design, implementation, accessibility, uptake and outcome. The low reporting of SES in trials could be due to trial reporting guidance documents, such as CONSORT 2010 statement (67), not considering equity. However, this limitation is counteracted somewhat by the extension of the CONSORT statement in 2017 with CONSORT-Equity (68). 
Since the latest study featured in the synthesis in this thesis was published in 2016, it is not possible to consider if the addition of CONSORT-Equity 2017 has improved the reporting of SES in trials, although recommendations about this have been around for some time (69).

The lack of SES data may be due to the exclusion of SES from pre-selected subgroup analyses. The studies identified in this review that did consider the variation of effectiveness of smoking cessation interventions by SES found no association, possibly due to the small number of participants in each group. This supports evidence from Inglis et al., (70) suggesting that subgroup analysis by SES often lacked methodological credibility. Given the time and resources involved with conducting clinical trials, it is unlikely that single studies are going to be sufficiently powered to avoid type II errors when considering the impact of interventions on inequalities.

Other systematic reviews have considered equity of smoking cessation interventions using data in addition to those from randomised controlled trials. Brown et al., considered the equity impact of European individual-level smoking cessation interventions (30). They found that NHS stop smoking services in the UK achieve equitable effects, and services which specifically targeted low-SES smokers achieved a higher uptake among low-SES smokers, which may attenuate the inequality gradient that exists for smoking cessation (14). This was supported in a more recent systematic review that focused solely on the UK which found that low-SES smokers were more likely to receive GP brief intervention or referral, but low-SES smokers were less successful at smoking abstinence (29). However, both reviews use a much broader definition of SES compared to this study and the other two previously discussed systematic reviews $(65,66)$ by including education level and occupation within the description of SES. The other reviews, and the PROGRESS-Plus criteria, separate education and occupation from SES.

Two trials highlighted in our study targeted individuals with low SES $(50,51)$, with evidence being mixed as to whether targeting interventions increases abstinence in this population. This targeting of interventions to those of a low-SES group was considered more extensively in a systematic review from Bull et al., (71). The review considered the effectiveness of targeted behavioural interventions for smoking cessation, physical activity and healthy eating. Post-intervention, there was a small but significant positive effect but this was not sustained in the longer term for smoking cessation or physical activity. This was supported by a rapid review from Vilhelmsson and Östergren (72) which found "no support for the notion that the methods used to reduce smoking decrease inequalities in health", and limited evidence that targeted interventions decrease inequalities in diet or physical activity. Consequently, future research should consider if targeted interventions for smoking cessation are effective, and this research needs to be more strongly theoretically driven than is currently the case.

\section{Strengths and Limitations}

Our search strategy was effective within the time and resource limitations available. Using Cochrane reviews, which only include high-quality RCTs, meant that we could highlight relevant literature that had been identified using comprehensive searching and evidence appraisal. Therefore, it is unlikely that we 
missed relevant research by only focusing on trials included in Cochrane reviews. We had regular discussions with topic experts which informed our methodological approach and allowed for greater consideration of the implications and the context of our findings.

The main limitation that arises from this approach is that our study is limited to literature published prior to the conducting of the searches by the authors of the Cochrane reviews. Hence, trials published since the conducting of each individual Cochrane review (date range 2013-2019) that meet each review's inclusion criteria post-hoc are not included. However, focusing only on RCTs meant that potentially relevant data from observational and other experimental studies were excluded. A further limitation of just using trials included in Cochrane reviews is the inconsistencies that exist in inclusion and exclusion criteria across the identified reviews. For example, differing restrictions were made in terms of study populations - some restricted trial eligibility to only including adults aged 18 and over, whilst others chose not to place such a restriction on eligible studies. We decided to not place this restriction across the literature identified in this review, due to different age restrictions for purchasing tobacco that exist globally and that some interventions may also target smokers that use tobacco before the local legal age of purchase. There is also small variation in the study designs included in Cochrane reviews; all reviews contain randomised trials (randomised controlled trials), whilst there is some scope to the range of randomised trial designs that are included (such as cluster-randomised, quasi-randomised or crossover trials). Some authors of Cochrane reviews choose to include non-randomised trials in addition to randomised trials, but this often depends on the scope of the research question and the breadth of the literature base (73). We focused only on randomised controlled trials in our study.

Furthermore, hand searching of additional literature was not performed. This may have led to omission of potentially relevant data that could have allowed deeper exploration of the research question. Similarly, only papers accessible via the University of Cambridge medical library and in the English language were used - although it was unlikely that the papers that were inaccessible would have changed our findings, as there was no mention of analysis by SES in study abstracts. A further limitation is that we did not consider the interventions systematically in terms of an available theoretical framework. Explicit use of theory may have allowed further understanding of the kinds of intervention most likely to impact on inequalities in smoking, for example considering if the level of agency required by the patient in interventions delivered by practitioners impacts upon inequalities.

\section{Implications}

Currently, trials of smoking cessation interventions delivered in primary care are not designed to allow analysis of effects by measures of SES. These trials generally do not report SES, and there is inconsistency in SES measures in those that do. The majority of studies that do collect data on SES do not analyse by it, and if they did then this analysis would likely be underpowered to assess interaction by SES. Pooling and meta-analysis of data by SES could mitigate this, although this is not currently possible due to infrequent and inconsistent reporting of SES. Our work highlights the need for routine reporting of 
SES in trials, especially in key areas of inequality such as lifestyle change and multimorbidity, and a greater consensus on measures. Consistent reporting of a core set of SES indicators will enable testing of similarities between trial groups and differential effects by SES. This could include absolute as well as relative measures of SES. Cochrane reviews should consider analysing by SES within their reviews. Responses to these implications should be informed by existing theory and evidence to demonstrate whether an improvement in total health and a reduction in inequality are achieved concurrently.

\section{Declarations}

\section{Ethics approval and consent to participate}

Not applicable

\section{Consent for publication}

Not applicable

\section{Availability of data and materials}

Data sharing is not applicable to this article as no datasets were generated or analysed during the current study.

\section{AUTHOR INFORMATION}

\section{Competing interests}

None

\section{Funding}

This project was completed as part of JMB's MPhil in Public Health, which was funding by the Department of Public Health and Primary Care, University of Cambridge. JMB is supported by the Medical Research Council (MRC) (Grant MC_UU_12015/4). The University of Cambridge has received salary support in respect of SJG from the National Health Service in the East of England through the Clinical Academic Reserve

\section{Authors' contributions}

JMB designed the study, conducted the literature search, selected trials for inclusion, extracted data and drafted the manuscript. HDM designed the study, helped interpretations of the data and provided revisions to the manuscript. SJG and MPK helped interpretations of the data and revisions to the manuscript. GBH selected trials for inclusion, extracted data and provided comments on the draft manuscript. ALK designed the study, helped with interpretations of the data and provided revisions to the manuscript. All authors read and approved the manuscript. 
Acknowledgements

Thank you to the members of the St John's Reading Group on Health Inequalities for their feedback on early project ideas and feedback on proposed methods.

\section{References}

1. Bauer UE, Briss PA, Goodman RA, Bowman BA. Prevention of chronic disease in the 21st century: elimination of the leading preventable causes of premature death and disability in the USA. The Lancet. 2014;384(9937):45-52.

2. Doll R, Peto R. Mortality in relation to smoking: 20 years' observations on male British doctors. $\mathrm{Br}$ Med J. 1976;2(6051):1525-36.

3. Brown KF, Rumgay H, Dunlop C, Ryan M, Quartly F, Cox A, et al. The fraction of cancer attributable to modifiable risk factors in England, Wales, Scotland, Northern Ireland, and the United Kingdom in 2015. British Journal of Cancer. 2018.

4. World Health Organization. Tobacco Key Facts. Geneva; 2019.

5. Jha P, Peto R. Global Effects of Smoking, of Quitting, and of Taxing Tobacco. New England Journal of Medicine. 2014;370(1):60-8.

6. Goodchild M, Nargis N, Tursan d'Espaignet E. Global economic cost of smoking-attributable diseases. Tobacco Control. 2018;27(1):58-64.

7. Ekpu VU, Brown AK. The Economic Impact of Smoking and of Reducing Smoking Prevalence: Review of Evidence. Tobacco use insights. 2015;8:1-35.

8. Allender S, Balakrishnan R, Scarborough P, Webster P, Rayner M. The burden of smoking-related ill health in the UK. Tob Control. 2009;18(4):262-7.

9. Action on Smoking and Health. The economics of tobacco. London; 2017.

10. O'Neill J, Tabish H, Welch V, Petticrew M, Pottie K, Clarke M, et al. Applying an equity lens to interventions: using PROGRESS ensures consideration of socially stratifying factors to illuminate inequities in health. Journal of clinical epidemiology. 2014;67(1):56-64.

11. Oliver S, Kavanagh J, Caird J, Lorenc T, Oliver K, Harden A, et al. Health promotion, inequalities and young people's health: a systematic review of research. London: EPPI-Centre, Social Science Research Unit, Institute of Education, University of London; 2008.

12. Galobardes B, Shaw M, Lawlor DA, Lynch JW, Davey Smith G. Indicators of socioeconomic position (part 1). J Epidemiol Community Health. 2006;60(1):7-12.

13. World Health Organization Regional Office for Europe. Tobacco and inequities. Guidance for addressing inequities in tobacco-related harm. Copenhagen; 2014.

14. Hiscock R, Judge $K$, Bauld L. Social inequalities in quitting smoking: what factors mediate the relationship between socioeconomic position and smoking cessation? Journal of Public Health. 2010;33(1):39-47. 
15. Cancer Research UK. Tobacco statistics London: Cancer Research UK; 2014 [23/07/2019]. Available from: https://www.cancerresearchuk.org/health-professional/cancer-statistics/risk/tobacco\#ref-4.

16. Santero M, Melendi S, Hernández-Vásquez A, Irazola V. Socio-economic inequalities in smoking prevalence and involuntary exposure to tobacco smoke in Argentina: Analysis of three crosssectional nationally representative surveys in 2005, 2009 and 2013. PLoS One. 2019;14(6):e0217845.

17. Sreeramareddy CT, Harper S. Trends in educational and wealth inequalities in adult tobacco use in Nepal 2001-2016: secondary data analyses of four Demographic and Health Surveys. BMJ Open. 2019;9(9):e029712.

18. Yaya S, Bishwajit G, Shah V, Ekholuenetale M. Socioeconomic Disparities in Smoking Behavior and Early Smoking Initiation Among Men in Malawi. Tobacco use insights. 2017;10:1179173X17726297$1179173 \mathrm{X}$.

19. Cai L, Wang X-M, Fan L-M, Cui W-L, Golden AR. Socioeconomic disparities in prevalence and behaviors of smoking in rural Southwest China. BMC public health. 2019;19(1):1117.

20. Di Cesare M, Khang YH, Asaria P, Blakely T, Cowan MJ, Farzadfar F, et al. Inequalities in noncommunicable diseases and effective responses. Lancet (London, England). 2013;381(9866):58597.

21. Meader N, King K, Moe-Byrne T, Wright K, Graham H, Petticrew M, et al. A systematic review on the clustering and co-occurrence of multiple risk behaviours. BMC Public Health. 2016;16(1):657.

22. Noble $\mathrm{N}$, Paul $\mathrm{C}$, Turon $\mathrm{H}$, Oldmeadow $\mathrm{C}$. Which modifiable health risk behaviours are related? $\mathrm{A}$ systematic review of the clustering of Smoking, Nutrition, Alcohol and Physical activity ('SNAP') health risk factors. Preventive Medicine. 2015;81:16-41.

23. Bauld L, Bell K, McCullough L, Richardson L, Greaves L. The effectiveness of NHS smoking cessation services: a systematic review. Journal of public health (Oxford, England). 2010;32(1):71-82.

24. Aveyard P, Begh R, Parsons A, West R. Brief opportunistic smoking cessation interventions: a systematic review and meta-analysis to compare advice to quit and offer of assistance. Addiction. 2012;107(6):1066-73.

25. West R, Raw M, McNeill A, Stead L, Aveyard P, Bitton J, et al. Health-care interventions to promote and assist tobacco cessation: a review of efficacy, effectiveness and affordability for use in national guideline development. Addiction. 2015;110(9):1388-403.

26. Jepson RG, Harris FM, Platt S, Tannahill C. The effectiveness of interventions to change six health behaviours: a review of reviews. BMC Public Health. 2010;10:538.

27. Hutt P, Gilmour S. Tackling inequalities in General Practice. London; 2010.

28. White M, Adams J, Heywood P. How and why do interventions that increase health overall widen inequalities within populations? . In: Babones SJ, editor. Social inequality and public health. Bristol: Policy Press; 2009.

29. Smith CE, Hill SE, Amos A. Impact of specialist and primary care stop smoking support on socioeconomic inequalities in cessation in the United Kingdom: a systematic review and national equity 
initial review. Addiction. 2019;0(0).

30. Brown T, Platt S, Amos A. Equity impact of European individual-level smoking cessation interventions to reduce smoking in adults: a systematic review. European Journal of Public Health. 2014;24(4):551-6.

31. Welch V, Petticrew M, Tugwell P, Moher D, O'Neill J, Waters E, et al. PRISMA-Equity 2012 Extension: Reporting Guidelines for Systematic Reviews with a Focus on Health Equity. PLOS Medicine. 2012;9(10):e1001333.

32. St John's Reading Group on Health Inequalities. About the Reading Group 2020 [03/03/2020]. Available from: https://www.joh.cam.ac.uk/st-johns-reading-group-health-inequalities.

33. Ouzzani M, Hammady H, Fedorowicz Z, Elmagarmid A. Rayyan-a web and mobile app for systematic reviews. Systematic Reviews. 2016;5(1):210.

34. University of Cambridge Medical Library. Databases for literature searching 2020 [03/03/2020]. Available from: https://library.medschl.cam.ac.uk/research-support/databases/.

35. van Schayck OCP, Williams S, Barchilon V, Baxter N, Jawad M, Katsaounou PA, et al. Treating tobacco dependence: guidance for primary care on life-saving interventions. Position statement of the IPCRG. NPJ Prim Care Respir Med. 2017;27(1):38-

36. Stead LF, Buitrago D, Preciado N, Sanchez G, Hartmann-Boyce J, Lancaster T. Physician advice for smoking cessation. Cochrane Database of Systematic Reviews. 2013(5).

37. Hollands GJ, McDermott MS, Lindson-Hawley N, Vogt F, Farley A, Aveyard P. Interventions to increase adherence to medications for tobacco dependence. The Cochrane database of systematic reviews. 2015(2):Cd009164.

38. Stead LF, Koilpillai P, Fanshawe TR, Lancaster T. Combined pharmacotherapy and behavioural interventions for smoking cessation. Cochrane Database of Systematic Reviews. 2016(3).

39. van Eerd EAM, van der Meer RM, van Schayck OCP, Kotz D. Smoking cessation for people with chronic obstructive pulmonary disease. Cochrane Database of Systematic Reviews. 2016(8).

40. Rice VH, Heath L, Livingstone-Banks J, Hartmann-Boyce J. Nursing interventions for smoking cessation. Cochrane Database of Systematic Reviews. 2017(12).

41. Lancaster T, Stead LF. Individual behavioural counselling for smoking cessation. Cochrane Database of Systematic Reviews. 2017(3).

42. Hartmann-Boyce J, Chepkin SC, Ye W, Bullen C, Lancaster T. Nicotine replacement therapy versus control for smoking cessation. Cochrane Database of Systematic Reviews. 2018(5).

43. Hartmann-Boyce J, Hong B, Livingstone-Banks J, Wheat H, Fanshawe TR. Additional behavioural support as an adjunct to pharmacotherapy for smoking cessation. Cochrane Database of Systematic Reviews. 2019(6).

44. Moher D, Liberati A, Tetzlaff J, Altman DG. Preferred reporting items for systematic reviews and meta-analyses: the PRISMA statement. BMJ. 2009;339. 
45. Higashi A, Ozasa K, Watanabe Y, Hayashi K, Aoike A, Kawai K, et al. [Efficacy of smoking cessation instruction for general smokers at an annual physical examination]. [Nihon koshu eisei zasshi] Japanese journal of public health. 1995;42(5):313-21.

46. Risser NL, Belcher DW. Adding spirometry, carbon monoxide, and pulmonary symptom results to smoking cessation counseling: a randomized trial. J Gen Intern Med. 1990;5(1):16-22.

47. Family Heart Study Group. Randomised controlled trial evaluating cardiovascular screening and intervention in general practice: principal results of British family heart study. Family Heart Study Group. BMJ. 1994;308(6924):313-20.

48. Ahluwalia JS, Okuyemi K, Nollen N, Choi WS, Kaur H, Pulvers K, et al. The effects of nicotine gum and counseling among African American light smokers: a 2 × 2 factorial design. Addiction. 2006;101(6):883-91.

49. Aveyard P, Griffin C, Lawrence T, Cheng KK. A controlled trial of an expert system and self-help manual intervention based on the stages of change versus standard self-help materials in smoking cessation. Addiction (Abingdon, England). 2003;98(3):345-54.

50. Bock BC, Papandonatos GD, de Dios MA, Abrams DB, Azam MM, Fagan M, et al. Tobacco cessation among low-income smokers: motivational enhancement and nicotine patch treatment. Nicotine \& tobacco research : official journal of the Society for Research on Nicotine and Tobacco. 2014;16(4):413-22.

51. Haas JS, Linder JA, Park ER, Gonzalez I, Rigotti NA, Klinger EV, et al. Proactive tobacco cessation outreach to smokers of low socioeconomic status: a randomized clinical trial. JAMA Intern Med. 2015;175(2):218-26.

52. Jamrozik K, Fowler G, Vessey M, Wald N. Placebo controlled trial of nicotine chewing gum in general practice. Br Med J (Clin Res Ed). 1984;289(6448):794-7.

53. Lancaster T, Dobbie W, Vos K, Yudkin P, Murphy M, Fowler G. Randomized trial of nurse-assisted strategies for smoking cessation in primary care. The British journal of general practice : the journal of the Royal College of General Practitioners. 1999;49(440):191-4.

54. Lou P, Zhu Y, Chen P, Zhang P, Yu J, Zhang N, et al. Supporting smoking cessation in chronic obstructive pulmonary disease with behavioral intervention: a randomized controlled trial. BMC Fam Pract. 2013;14:91.

55. Marshall A, Raw M. Nicotine chewing gum in general practice: effect of follow up appointments. $\mathrm{Br}$ Med J (Clin Res Ed). 1985;290(6479):1397-8.

56. Marteau TM, Aveyard P, Munafò MR, Prevost AT, Hollands GJ, Armstrong D, et al. Effect on Adherence to Nicotine Replacement Therapy of Informing Smokers Their Dose Is Determined by Their Genotype: A Randomised Controlled Trial. PLoS One. 2012;7(4):e35249.

57. Imperial Cancer Research Fund OXCHECK Study Group. Effectiveness of health checks conducted by nurses in primary care: results of the OXCHECK study after one year. Imperial Cancer Research Fund OXCHECK Study Group. Bmj. 1994;308(6924):308-12. 
58. Richmond RL, Makinson RJ, Kehoe LA, Giugni AA, Webster IW. One-year evaluation of three smoking cessation interventions administered by general practitioners. Addictive behaviors. 1993;18(2):18799.

59. Sanders D, Fowler G, Mant D, Fuller A, Jones L, Marzillier J. Randomized controlled trial of antismoking advice by nurses in general practice. The Journal of the Royal College of General Practitioners. 1989;39(324):273-6.

60. Stanton CA, Papandonatos GD, Shuter J, Bicki A, Lloyd-Richardson EE, de Dios MA, et al. Outcomes of a Tailored Intervention for Cigarette Smoking Cessation Among Latinos Living With HIV/AIDS. Nicotine \& tobacco research : official journal of the Society for Research on Nicotine and Tobacco. 2015;17(8):975-82.

61. van Rossem C, Spigt M, Viechtbauer W, Lucas AEM, van Schayck OCP, Kotz D. Effectiveness of intensive practice nurse counselling versus brief general practitioner advice, both combined with varenicline, for smoking cessation: a randomized pragmatic trial in primary care. Addiction (Abingdon, England). 2017;112(12):2237-47.

62. Williams GC, Gagne M, Ryan RM, Deci EL. Facilitating autonomous motivation for smoking cessation. Health psychology : official journal of the Division of Health Psychology, American Psychological Association. 2002;21(1):40-50.

63. Zwar NA, Richmond RL, Halcomb EJ, Furler JS, Smith JP, Hermiz O, et al. Quit in general practice: a cluster randomized trial of enhanced in-practice support for smoking cessation. Family practice. 2015;32(2):173-80.

64. Wewers ME, Ferketich AK, Harness J, Paskett ED. Effectiveness of a nurse-managed, lay-led tobacco cessation intervention among ohio appalachian women. Cancer epidemiology, biomarkers \& prevention : a publication of the American Association for Cancer Research, cosponsored by the American Society of Preventive Oncology. 2009;18(12):3451-8.

65. Attwood S, van Sluijs E, Sutton S. Exploring equity in primary-care-based physical activity interventions using PROGRESS-Plus: a systematic review and evidence synthesis. The international journal of behavioral nutrition and physical activity. 2016;13:60.

66. Smith SM, Soubhi H, Fortin M, Hudon C, O’Dowd T. Managing patients with multimorbidity: systematic review of interventions in primary care and community settings. BMJ : British Medical Journal. 2012;345:e5205.

67. Schulz KF, Altman DG, Moher D. CONSORT 2010 Statement: updated guidelines for reporting parallel group randomised trials. BMJ. 2010;340:c332.

68. Welch VA, Norheim OF, Jull J, Cookson R, Sommerfelt H, Tugwell P. CONSORT-Equity 2017 extension and elaboration for better reporting of health equity in randomised trials. BMJ. 2017;359:j5085.

69. Tugwell P, Petticrew M, Kristjansson E, Welch V, Ueffing E, Waters E, et al. Assessing equity in systematic reviews: realising the recommendations of the Commission on Social Determinants of Health. BMJ. 2010;341:c4739. 
70. Inglis G, Archibald D, Doi L, Laird Y, Malden S, Marryat L, et al. Credibility of subgroup analyses by socioeconomic status in public health intervention evaluations: An underappreciated problem? SSM Population Health. 2018;6:245-51.

71. Bull ER, Dombrowski SU, McCleary N, Johnston M. Are interventions for low-income groups effective in changing healthy eating, physical activity and smoking behaviours? A systematic review and meta-analysis. BMJ Open. 2014;4(11):e006046.

72. Vilhelmsson A, Östergren P-O. Reducing health inequalities with interventions targeting behavioral factors among individuals with low levels of education - A rapid review. PLoS One. 2018;13(4):e0195774-e.

73. McKenzie J, Brennan S, Ryan R, Thomson H, Johnston R, Thomas J. Chapter 3: Defining the criteria for including studies and how they wil be grouped for the synthesis. In: Higgins $J$, Thomas J, Chandler J, Cumpston M, Li T, Page M, et al., editors. Cochrane Handbook for Systematic Reviews of Interventions version 60 (updated July 2019): Cochrane; 2019.

\section{Figures}



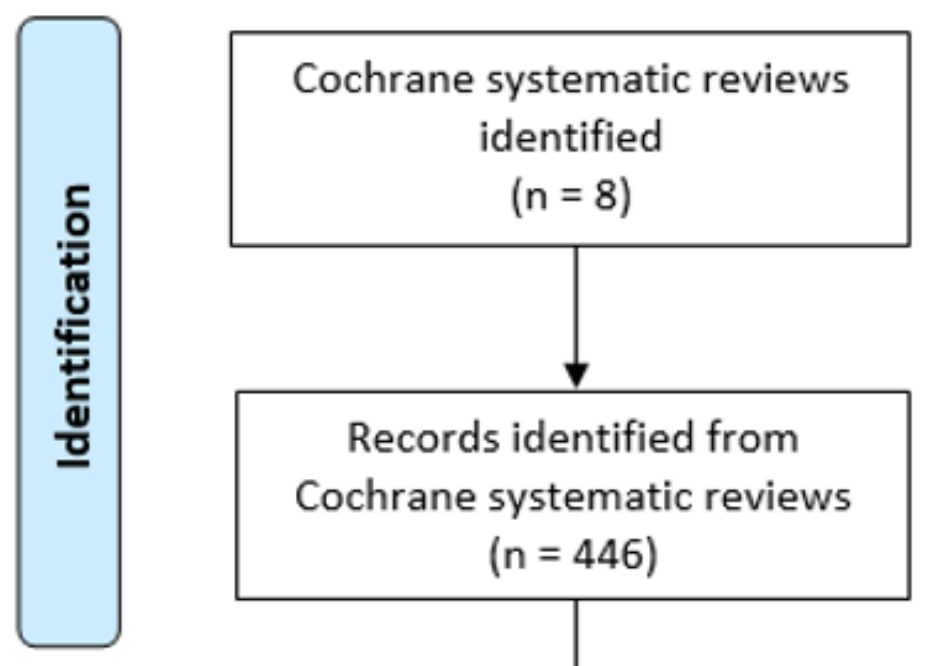

\section{Records identified from}

Cochrane systematic reviews

$$
\text { ( } n=446)
$$
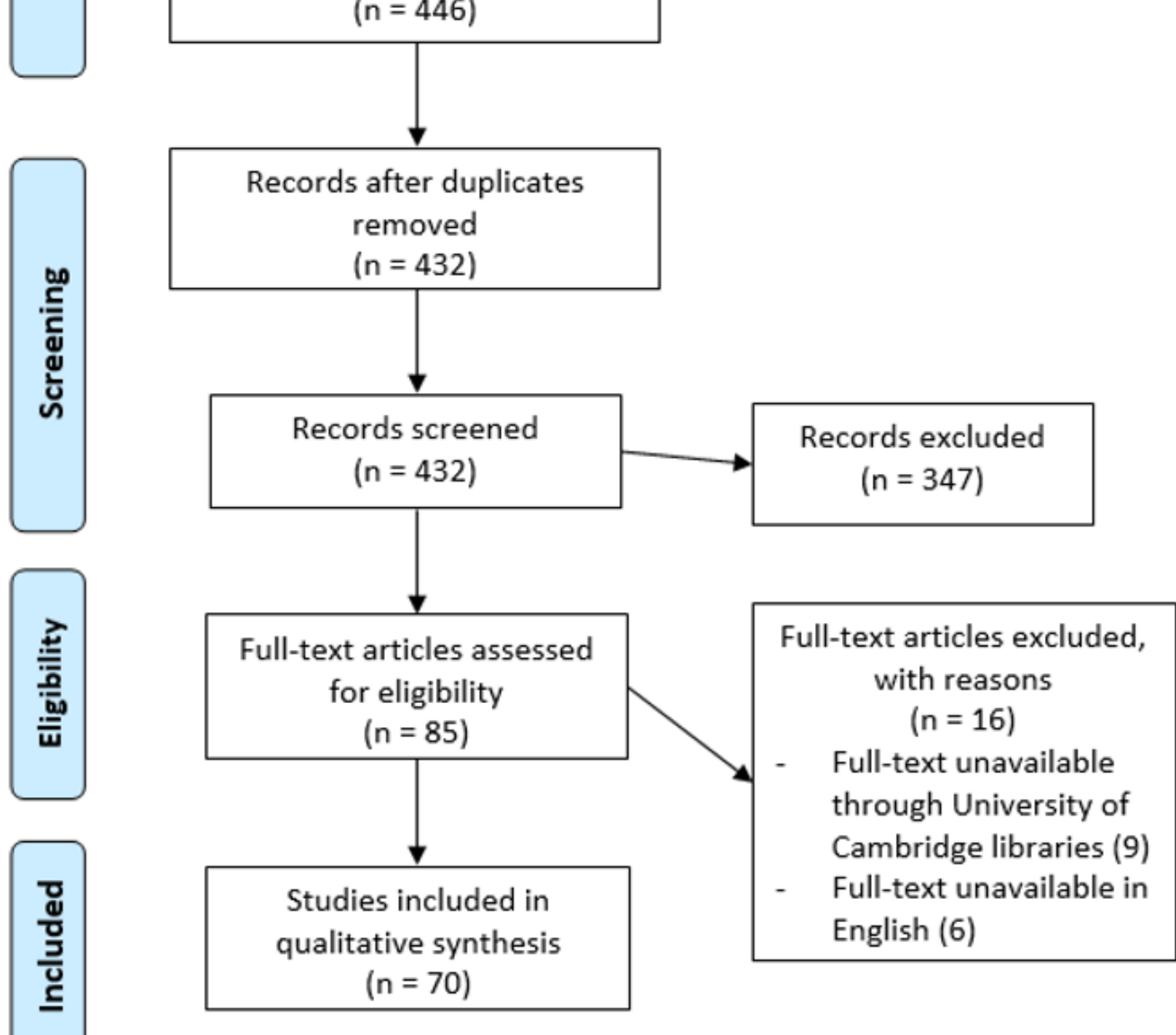

\section{Figure 1}

PRISMA flow diagram

\section{Supplementary Files}

This is a list of supplementary files associated with this preprint. Click to download. 
- AdditionalFile2AllEligibleStudies.docx

- AdditionalFile1PRISMAEquityChecklist.docx 